\title{
IN SEARCH OF REFUGE: \\ The United States’ DOMESTiC AND InTERnATIONAL Obligations to Protect UNACCOMPANIED IMMIGRANT CHILDREN
}

\author{
Megan Smith-Pastrana*
}

"They undertake difficult journeys, often across numerous international borders, and often alone. Unaccompanied children are some of the most vulnerable migrants who cross our borders, and are in need of special protections appropriate for their situation."

"Abuse at the hands of immigration officers and agents compounds the trauma and abuse that many of these children have already suffered. Greater oversight and accountability is needed for $C B P$ as it encounters and interacts with children, many of whom have fled violence and persecution in their home countries and are in the aftermath of a dangerous journey here. Shortterm detention facilities must also be regulated and improved as they are the first stop for the children in the process.",2

\section{MELVIN’S STORY}

In search of protection from the gang violence in El Salvador, Melvin made the extremely difficult journey of coming to the United States unaccompanied and illegally. ${ }^{3}$ With one of the highest per capita murder rates in the world, El Salvador is considered one of the most dangerous

\footnotetext{
* Candidate for Doctor of Jurisprudence and Graduate Certificate in International and Comparative Law, Indiana University Robert H. McKinney School of Law, 2016. Received Best Student Note Award for the 2015 selection cycle. To my Mom, Dad, Grandparents, and my husband Carlos Pastrana for your love and support during my journey through law school. I am extremely grateful to Professor Karen E. Bravo for her guidance and assistance in writing this Note. Furthermore, thank you to my mentors, Attorney Aimee Heitz and Noemí Gallegos for sharing with me your knowledge of and passion for the field of immigration.

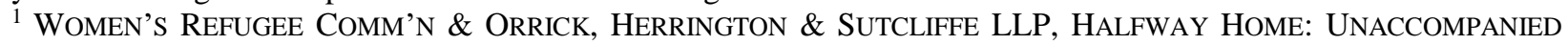
CHILDREN IN IMMIGRATION CUSTODY 1 (2009), http://www.womensrefugeecommission.org/programs/migrantrights/unaccompanied-children [http://perma.cc/DY67-PKWF] (follow Halfway Home: Unaccompanied Children in Immigration Custody hyperlink) [hereinafter HALFWAY HOME].

${ }^{2}$ Statement of the American Immigration Lawyers Association Submitted to the Committee on the Judiciary of the U.S. House of Representatives Hearing on "An Administration Made Disaster: The South Texas Border Surge of Unaccompanied Alien Minors,” AM. IMMIGR. LAWYERS ASS'N (June 25, 2014),

http://www.aila.org/content/default.aspx?docid=49015 [http://perma.cc/FMR9-MFKP] [hereinafter Statement of the American Immigration Lawyers Association].

${ }^{3}$ Corinne Lestch, Children who crossed the border recall horror stories back home as they fight to stay in U.S., N.Y. DAILY NEWS (Aug. 13, 2014, 10:20 PM), http://www.nydailynews.com/news/national/immigrant-kids-judge-horrorstories-article-1.1902877 [http://perma.cc/RK7H-SMYH].
} 
coluntries. ${ }^{4}$ For many children, the decision to come to the United States is a decision of life or death. ${ }^{5}$ In recalling his life in El Salvador, Melvin describes that "[w]hen kids leave school, (the gang members) come up to you and wrap their arms around you like they're your friend .... And then they put a pistol on your waist and tell you to come with them." ${ }^{6}$ Melvin is one of the thousands of unaccompanied minors who entered the United States illegally since the start of the 2014 fiscal year. $^{7}$

\section{INTRODUCTION}

Unfortunately, for many of these children, the treacherous journey does not stop once they cross into the United States. ${ }^{8}$ Children without a legal guardian in the United States to whom they can be released while their immigration case is pending are placed in the custody of immigration. ${ }^{9}$ There are numerous reports of severe abuse and mistreatment of the children under the care of the United States Custom and Border Protection (“CBP”). ${ }^{10}$ The reports include children being shackled, refused proper medical care, and being physically, emotionally and sexually abused. ${ }^{11}$ Instead of finding the refuge they so desperately need, the children are crowded into detention centers to face inhumane living conditions and horrendous acts of mistreatment. ${ }^{12}$

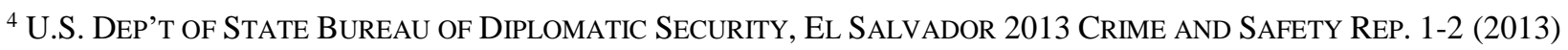
("El Salvador has the second highest per capita murder rate in the world: 69:100,000 in 2012 (UNODC statistics) (by comparison the murder rate in Massachusetts, with a similar geographical area and population, was 2.6 per 100,000).").

${ }^{5}$ Lestch, supra note 3.

${ }^{6} I d$.

${ }^{7}$ Statement of the American Immigration Lawyers Association, supra note 2.

${ }^{8}$ See Halfway Home, supra note 1, at 4. The Women's Refugee Commission completed a study regarding the care and custody of unaccompanied alien children in immigration custody. The report provides a firsthand insight on the shortcoming of the current system in place and will be referenced several times throughout this Note.

${ }^{9} I d$. at 1 .

${ }^{10}$ Statement of the American Immigration Lawyers Association, supra note 2 ("A report by the American Immigration Council shows over 800 complaints received by CBP from 2009-2012 . . .”).

${ }^{11} I d$.

${ }^{12}$ Unaccompanied Immigrant Children Report Serious Abuse by U.S. Officials During Detention, AM. CIV. LIBERTIES UNION (June 11, 2014), https://www.aclu.org/immigrants-rights/unaccompanied-immigrant-children-report-seriousabuse-us-officials-during [http://perma.cc/V745-G6XA] [hereinafter AM, CIV. LIBERTIES UNION].
} 
This Note will discuss the United States' failure to adhere to its current domestic laws and to international conventions and customs regarding the humane treatment of immigrant children. There are extreme human rights violations occurring within the United States, and it is imperative that changes be made to the current system in order to comply with not only domesticallyimplemented obligations, but also with international conventions and customs. Specific changes that must be made for the United States to come into compliance with its obligations include codification of the Flores Settlement Agreement, ${ }^{13}$ ratification of the Convention of the Rights of the Child, ${ }^{14}$ and a detention system with a focus on the "best interest of the child" principle. Additionally, the United States should provide meaningful access to legal counsel and eliminate the use of expedited removal. Finally, the United States must take foreign policy initiatives to address the reasons why the children are fleeing their countries of origin.

Section II of this Note will examine the current landscape of immigration issues surrounding unaccompanied immigrant children in the United States. ${ }^{15}$ Section III will provide an analysis of the domestic and international laws and customs pertaining to the treatment of immigrants. Section IV will make a comparative analysis between the United States' current immigration policies with those of Sweden and the United Kingdom. Section V of the Note will review the material presented and provide potential solutions for how the United States can make changes within its system to comply with its domestic and international obligations to unaccompanied immigrant children. Finally, Section VI of the Note will summarize the solutions

\footnotetext{
${ }^{13}$ Stipulated Settlement Agreement, Flores v. Reno, No. 85-4544 (C.D. Cal. Jan. 17, 1997), https://cliniclegal.org/sites/default/files/attachments/flores_v._reno_settlement_agreement_1.pdf [http://perma.cc/J3QF-5L8L] [hereinafter Flores Settlement Agreement].

${ }^{14}$ Convention on the Rights of the Child, Nov. 20, 1989, 1577 U.N.T.S. 3, http://www.ohchr.org/en/professionalinterest/pages/crc.aspx [http://perma.cc/TXR6-BR4A] [hereinafter CRC].

15 This Note will focus specifically on the recent increase of unaccompanied children arriving to the U.S. from Mexico, El Salvador, Guatemala, and Honduras.
} 
presented and explain how fulfillment of those objectives will provide the most appropriate humanitarian protection for unaccompanied immigrant children.

\title{
II. BACKGROUND AND HISTORY:
}

\section{UNACCOMPANIED IMMIGRANT CHILDREN IN THE UNITED STATES}

On June 2, 2014, in response to hundreds of unaccompanied immigrant children crossing the United States' southwest border, President Obama declared an "urgent humanitarian crisis."16 In 2011, approximately 4,059 unaccompanied immigrant children from Mexico, El Salvador, Honduras, and Guatemala entered the United States in search of refuge. ${ }^{17}$ In fiscal year 2014, the U.S. Border Patrol agents apprehended 66,127 unaccompanied immigrant children. ${ }^{18}$ The U.S. Senate Appropriations Committee further estimates that the number of unaccompanied children will continue to increase to around 127,000 to 145,000 unaccompanied children in $2015 .{ }^{19}$ This Note focuses specifically on the recent increase in children arriving to the United States from Mexico, El Salvador, Guatemala, and Honduras.

\section{A. Why ARE ThousAnds of CHILDREN CROSSING THE UNITED STATES BordeR}

\author{
Alone?
}

\footnotetext{
16 Devin Dwyer, Obama Calls Surge of Children Across US Border 'Urgent Humanitarian Situation', ABC NEwS (June 2, 2014), http://abcnews.go.com/blogs/politics/2014/06/president-obama-calls-surge-of-children-across-usborder-urgent-humanitarian-situation/ [http://perma.cc/37UW-ZC47].

${ }^{17}$ Dara Lind, Thousands of children are fleeing Central America to Texas-alone, VOX (June 4, 2014, 8:00 AM), http://www.vox.com/2014/6/4/5773268/children-migration-central-america-texas-unaccompanied-alien-childrenborder-crisis [http://perma.cc/2B3G-6H6P].

${ }^{18}$ Muzaffar Chishti \& Faye Hipsman, Unaccompanied Minors Crisis Has Receded from Headlines But Major Issues Remain, MigRATION POL'Y INST. (Sept. 25, 2014), http://www.migrationpolicy.org/article/unaccompanied-minorscrisis-has-receded-headlines-major-issues-remain [http://perma.cc/MY5R-R4B7].

${ }^{19}$ U.S. S. Comm. on Appropriations, Opening Statement of Chairwoman Barbara A. Mikulski (June 10, 2014), http://www.appropriations.senate.gov/sites/default/files/hearings/06_10_14\%20lhhs\%20markup\%20bam\%20remark s\%20w\%20UAC\%20intro.pdf [http://perma.cc/3AUU-5UX7].
} 
The United Nations High Commissioner for Refugees ("UNHCR") completed a study to determine the reasons for why children are fleeing their home countries of Mexico, Honduras, El Salvador, and Guatemala. ${ }^{20}$ The study found that " $[\mathrm{t}]$ wo overarching patterns of harm related to potential international protection needs emerged: violence by organized armed criminal actors and violence in the home." ${ }^{21}$ Forty-eight percent of the children interviewed "shared experiences of how they had been personally affected by the augmented violence in the region by organized armed criminal actors, including drug cartels and gangs or by State actors." ${ }^{22}$ Twenty-one percent indicated that the reason for fleeing their country of origin was "abuse and violence in their homes by their caretakers." ${ }^{23}$ Eleven percent of the children interviewed "reported having suffered or being in fear of both violence in society and abuse in the home." ${ }^{24}$ Finally, thirty-eight percent of the children, specifically children from Mexico, were escaping "recruitment into and exploitation by the criminal industry of human smuggling — that is, facilitating others in crossing into the United States unlawfully.",25

\footnotetext{
${ }^{20}$ U.N. High COMm'R For Refugees Regional OfFICE FOR The U.S. AND THE CARIBBEAN, ChILDREN ON THE Run: UnACCOMPANIED CHILdREN LEAVING CENTRAL AMERICA AND MEXICO AND THE NEED FOR INTERNATIONAL PROTECTION 6 (May 2014), http://www.unhcrwashington.org/sites/default/files/1_UAC_Children\%200n\%20the\%20Run_Executive\%20Summa ry.pdf [http://perma.cc/4PY6-BDDH] [hereinafter CHILDREN ON THE RUN].

${ }^{21} I d$. Protection related reasons were found to be a very prominent trend in the data collected. The data from the survey revealed "that no less than $58 \%$ of the 404 children interviewed were forcibly displaced because they suffered or faced harms that indicated a potential or actual need for international protection." Id.

${ }^{22} I d$. The report divided the results by country, and children from El Salvador and Honduras were found to have the highest potential for international protection needs with $72 \%$ and $57 \%$ of total number for unaccompanied minors from each state. $I d$.

${ }^{23} I d$.

${ }^{24} I d$. at 7.

${ }^{25} I d$. at 6-7. The "push factors" are not the only variables contributing to the recent surge in unaccompanied minors arriving to the U.S. Child Migrants to the United States, NAT'L CONF. OF STATE LEGISLATURES (revised Oct. 28, 2014), http://www.ncsl.org/research/immigration/child-migrants-to-the-united-states.aspx [http://perma.cc/J7R6TPDW] [hereinafter NAT'L CONF. OF STATE LEGISLATURES]. For many children escaping violence in their home countries, their decision was also driven by the "pull factor" of wanting to reunite with family in the United States. Id.
} 
Given that the unaccompanied minors are escaping from such serious circumstances, the importance of conducting interviews with each child and completing reports regarding each child's circumstances is extremely important. ${ }^{26}$ Knowing and understanding the reasons why a child has escaped his or her country to come to the United States is the only way to ensure that children will receive the required international protection. ${ }^{27}$

\section{B. Detention of Immigrant ChiLdRen In the United States}

The Homeland Security Act ("HSA") of 2002 transferred the custody of unaccompanied children from the Immigration and Naturalization Service ("INS") to the Office of the Refugee Resettlement (“ORR"). ${ }^{28}$ ORR then created a division called the Department of Unaccompanied Children's Services ("DUCS"), which in turn contracted with private facilities to provide the needed services and care to unaccompanied minors. ${ }^{29}$ Currently, most immigrant children are housed in the private facilities operated by DUCS. ${ }^{30}$ In order to analyze the effectiveness of the transfer, the Women's Refugee Commission conducted a study in 2009 of the privately held DUCS facilities. ${ }^{31}$ While the Women's Refugee Commission noted that the children are better off under the care of the DUCS as opposed to the INS, there are still numerous pitfalls within the newly implemented system. ${ }^{32}$

A main shortfall of the system is that DUCS maintains dual roles of "prosecutor and caretaker." ${ }^{33}$ These competing roles have led to the location of facilities in remote locations to

\footnotetext{
${ }^{26}$ See CHILDREN ON THE RUN, supra note 20, at 7.

${ }^{27} \mathrm{Id}$.

${ }^{28} 6$ U.S.C. § 279(a) (2006).

${ }^{29}$ HALFWAY HOME, supra note 1 , at 4 .

${ }^{30} \mathrm{Id}$.

${ }^{31} \mathrm{Id}$.

${ }^{32} I d$. at 14.

${ }^{33} \mathrm{Id}$.
} 
facilitate transfer between Department of Homeland Security ("DHS") and DUCS. ${ }^{34}$ Remote areas provide little to no access for children to medical and legal services. ${ }^{35}$ Furthermore, DUCS facilities unable to handle large numbers of children more closely resemble the restrictive settings of prisons or juvenile detention centers, which compromise the "best interest of the child." 36 Additionally, many of the private DUCS facilities, as a result of little to no oversight, have failed to comply with proper policies and procedures. ${ }^{37}$ The lack of oversight leaves children subject to not only harsh living conditions, but also to physical and mental abuse. ${ }^{38}$

Since the Women's Refugee Commission report of 2009, the brokenness of the immigration system continues to show, as the flood of unaccompanied immigrant children entering the United States increases. ${ }^{39}$ While DHS has made improvements in the system by attempting to shorten the length of time children spend in detention and to improve the care and treatment of children, the abuse of children in detention facilities persists. ${ }^{40}$ Numerous complaints were filed against DUCS facilities for abuse and neglect of children. ${ }^{41}$ Recently filed complaints include details "that children were shackled, subjected to inhumane detention conditions, had inadequate access to medical care, and were verbally, sexually, and physically abused." $" 2$

On June 11, 2014, the American Civil Liberties Union (“ACLU”), along with other civil, immigrant, and human rights groups, filed a complaint on behalf of more than one hundred

${ }^{34} I d$.

${ }^{35} I d$.

${ }^{36} I d$. at 15,18 .

${ }^{37}$ Id. at $24-5$.

${ }^{38} \mathrm{Id}$. at 24.

${ }^{39}$ A Fair and Responsible Response to the Recent Influx of Unaccompanied Immigrant Minors, THE CHI. BAR FOUND. (Aug. 5, 2014), http://chicagobarfoundation.org/news_item/fair-responsible-response-recent-influx-unaccompaniedimmigrant-minors/ [http://perma.cc/ZX4F-PFE7].

${ }^{40}$ American Immigration Lawyers Association, supra note 2.

${ }^{41} \mathrm{Id}$.

${ }^{42} I d$. 
children who had reported abuse and mistreatment at the hands of CBP. ${ }^{43}$ The managing attorney for the Immigrant Children's Protection Project at the National Immigrant Justice Center made the following statement with regard to the current treatment of unaccompanied minors:

Border Patrol agents are committing appalling abuses of children all along the border. Even worse, Border Patrol has been committing these abuses for years, and our organizations have notified the agency numerous times, yet nothing has changed. The recent increase in arrivals of young people at the border makes it especially urgent that CBP ensure all children in their custody are treated safely and humanely. ${ }^{44}$

Among the reports of abuse referenced in the ACLU complaint, is that of a fourteen-yearold girl who was forced to stay in an unsanitary and overcrowded holding cell after having her asthma medication confiscated by the CBP agent. ${ }^{45}$ While in the cell, the young girl suffered from multiple asthma attacks. ${ }^{46}$ The CBP officials refused to assist her and only threatened her with punishment for faking. ${ }^{47}$

Another seventeen-year-old girl was placed in what is referred to as a hielera, or freezer, in her wet clothes. ${ }^{48}$ The hielera prevented her clothes from drying for three whole days. ${ }^{49}$ Additionally, CBP did not provide the girl any drinking water, leaving her only with the water

\footnotetext{
${ }^{43}$ AM. CIV. LiBerTIES UNION, supra note 12 ("The complaint describes Border Patrol agents denying necessary medical care to children as young as five-months-old, refusing to provide diapers for infants, confiscating and not returning legal documents and personal belongings, making racially-charged insults and death threats, and strip searching and shackling children in three-point restraints during transport. Reports of such abuse have been documented and reported for years, but no reforms have been implemented, nor have any actions been taken to hold agents accountable.").

${ }^{44}$ Id. James Lyall of the ACLU commented, "Border agents operate in a zone of impunity. Given CBP's recent promise to be more accountable and transparent, we call on the agency to finally address these systemic abuses in a serious and meaningful way." Id.

${ }^{45} I d$.

${ }^{46} I d$.

${ }^{47} I d$.

${ }^{48} I d$.

${ }^{49} I d$.
} 
from the toilet in her cell, which was in plain view of all of the other detainees and located in front of one of the security cameras. ${ }^{50}$

An additional report of abuse includes a seven-year-old boy who was developmentally disabled. ${ }^{51}$ When he was detained by CBP he was suffering from acute malnourishment, yet CBP held him in custody for five days and refused him medical treatment. ${ }^{52}$ He ultimately was released from CBP and required surgery and hospitalization. ${ }^{53}$

The stories of these young children shed light on the horrendous abuses of children within the United States' immigration system. ${ }^{54}$ Unfortunately, the reports of abuse of children at the hands of border patrol agents are not a new occurrence. ${ }^{55}$ From January 2009 through January 2012, approximately 809 complaints of alleged abuse were lodged against Border Patrol agents. ${ }^{56}$ As the influx of unaccompanied minors continues to grow, the brokenness of the current system becomes even more apparent. ${ }^{57}$ On June 25, 2014, the American Immigration Lawyers Association ("AILA") urged the U.S. House of Representatives and the Administration to take the complaints against CBP officials seriously in an effort to prevent continued abuse. ${ }^{58}$ Furthermore, AILA urged the Administration to implement "greater oversight and accountability" for CBP noting that

${ }^{50} I d$.

${ }^{51} I d$.

${ }^{52} I d$.

${ }^{53} I d$.

${ }^{54}$ AM. CIV. LIBERTIES UNION, supra note 12.

${ }^{55}$ No Action Taken: Lack of CBP Accountability in Responding to Complaints of Abuse, IMMIGR. POL'Y CTR. (May 4, 2014), http://www.immigrationpolicy.org/special-reports/no-action-taken-lack-cbp-accountability-respondingcomplaints-abuse [http://perma.cc/V8NQ-PTY7].

${ }^{56} I d$.

${ }^{57} \mathrm{Id}$.

58 Statement of the American Immigration Lawyers Association, supra note 2 ("AILA recognizes that most officers and agents perform their jobs professionally and do not engage in abuses. However, the Administration should take these complaints seriously to ensure that the culture at CBP does not accept abuse. Abuse at the hands of immigration officers and agents compounds the trauma and abuse that many of these children have already suffered. Greater oversight and accountability is needed for CBP as it encounters and interacts with children, many of whom have fled violence and persecution in their home countries and are in the aftermath of a dangerous journey here. Short-term detention facilities must also be regulated and improved as they are the first stop for the children in the process."). 
"[a]buse at the hands of immigration officers and agents compounds the trauma and abuse that many of these children have already suffered." 59

\section{ANALYSIS: DOMESTIC AND INTERNATIONAL LAWS REGARDING THE}

\section{TREATMENT OF UNDOCUMENTED IMMIGRANTS}

The United States' obligation to treat unaccompanied minors and undocumented immigrants in a humane manner is rooted in both domestic and international law. ${ }^{60}$ This Note will specifically explore the domestic obligations created by the Flores Settlement Agreement. ${ }^{61}$ Additionally, this Note will analyze the United States' international obligations under the Convention on the Rights of the Child ("CRC") ${ }^{62}$ along with the Convention Relating to the Status of Refugees ("CRSR"). ${ }^{63}$ In finding an adequate solution to remedy the shortcomings of the current immigration system, it is vital that the United States takes into consideration both its domestic and international obligations. ${ }^{64}$

\section{A. The Flores SetTlement AgreEMENT}

In 1985, Jenny Flores fled the violence of El Salvador in an attempt to find safety in the home of her aunt in the United States. ${ }^{65}$ The INS detained Jenny before she could reach her aunt's home. ${ }^{66}$ While in INS custody, Jenny was " "handcuffed, strip searched, and placed ... in a juvenile detention center where she spent the next two months waiting for her deportation hearing." ${ }^{67}$

\footnotetext{
${ }^{59} I d$.

${ }^{60} \mathrm{Id}$.

${ }^{61}$ Flores Settlement Agreement, supra note 13.

${ }^{62}$ CRC, supra note 14 , art. 3.

${ }^{63}$ Convention Relating to the Status of Refugees, opened for signature July 28, 1951, 19 U.S.T. 6259, 189 U.N.T.S. 150 [hereinafter Convention].

${ }^{64}$ Statement of the American Immigration Lawyers Association, supra note 2.

${ }^{65}$ Rebecca M. Lopez, Comment, Codifying the Flores Settlement Agreement: Seeking to Protect Immigrant Children in U.S. Custody, 95 Marq. L. Rev. 1635, 1648 (2012).

${ }^{66} \mathrm{Id}$.

${ }^{67} \mathrm{Id}$.
} 
Jenny's experience, along with that of four other minors, became part of the Flores $v$. Reno case filed by the ACLU. ${ }^{68}$ The lawsuit contested the manner in which the INS apprehended, detained, and released immigrant children in its custody. ${ }^{69}$

The case eventually resulted in the Flores v. Reno Settlement Agreement ("FSA"). ${ }^{70}$ In 1997, a California federal court approved the agreement, which set forth national standards and responsibilities for the INS in the detention, release, and treatment of children under INS custody. ${ }^{71}$ Since 1997, the FSA has governed how both unaccompanied and accompanied children are treated while in the custody of the federal government. ${ }^{72}$ Two main provisions of the FSA include placing the minor in the least restrictive setting and treating the minor with dignity. ${ }^{73}$ Section eleven of the agreement provides:

The INS treats, and shall continue to treat, all minors in its custody with dignity, respect and special concern for their particular vulnerability as minors. The INS shall place each detained minor in the least restrictive setting appropriate to the minor's age and special needs, provided that such setting is consistent with its interests to ensure the minor's timely appearance before the INS and the immigration courts and to protect the minor's well-being and that of others. Nothing herein shall require the INS to release a minor to any person or agency whom the INS has reason to believe may harm or neglect the minor or fail to present him or her before the INS or the immigration courts when requested to do so. ${ }^{74}$

The FSA further requires that the INS "hold minors in facilities that are safe and sanitary and that are consistent with the INS's concern for the particular vulnerability of minors."75

\footnotetext{
${ }^{68} I d$.

${ }^{69}$ Fact Sheet: Children Detained by the Department of Homeland Security in Adult Detention Facilities, NAT'L IMMIGRANT JUST. http://www.immigrantjustice.org/sites/immigrantjustice.org/files/NIJC\%20Fact\%20Sheet\%20Minors\%20in\%20ICE $\%$ 20Custody\%202013\%2005\%2030\%20FINAL.pdf [http://perma.cc/9F6Z-2VET] (last visited September 28, 2014).

${ }^{70}$ Flores Settlement Agreement, supra note 13.

${ }^{71}$ NAT'L IMMIGRANT JUST. CTR., supra note 69.

${ }^{72}$ Lopez, supra note 65, at 1642.

${ }^{73}$ Flores Settlement Agreement, supra note 13, at 11.

${ }^{74}$ Id.

${ }^{75} \mathrm{Id}$. at 12 .
} 
Furthermore, facilities are required to "provide access to toilets and sinks, drinking water and food as appropriate, medical assistance if the minor is in need of emergency services, adequate temperature control and ventilation, adequate supervision to protect minors from others, and contact with family members who were arrested with the minor.",76

While the FSA confers legal obligations on the United States' immigration system, the INS has frequently been found to not be in compliance with the guidelines. ${ }^{77}$ The failure to comply has largely been a result of the lack of oversight and enforcement mechanisms of the FSA. ${ }^{78}$ Many sections of the FSA have been codified, and the codified sections of the FSA include provisions regarding the detention and release of juveniles. ${ }^{79}$ The codified section of the FSA regarding the detention of juveniles provides that

In the case of a juvenile for whom detention is determined to be necessary, for such interim period of time as is required to locate suitable placement for the juvenile . . . the juvenile may be temporarily held by Service authorities or placed in any Service detention facility having separate accommodations for juveniles. ${ }^{80}$

\footnotetext{
${ }^{76} I d$.

${ }^{77}$ Lopez, supra note 65, at 1644. On February 2, 2015, the Youth Law Center and other organizations filed a motion in U.S. District Court challenging the Department of Homeland Security's ("DHS") no-release policy for women and children arriving from Central America. Notice of Motion and Motion to Enforce Settlement of Class Action, Flores v. Johnson, No. CV 85-4544-RJK(Px) at 8-9 (C.D. Cal. Feb. 2, 2015), http://www.ylc.org/wp/wpcontent/uploads/Flores\%20Notice\%20of\%20Motion\%20and\%20Memorandum\%20to\%20Enforce\%20Settlement.pd f [http://perma.cc/X26Z-QMZ7]. Judge Dolly Gee of the Central District of California found the Defendants' norelease policy to be a material breach of the 1997 FSA agreement, specifically noting the provision barring immigrant children from being held in secure facilities. In Chambers-Order re Plaintiff's Motion, Flores v. Johnson, No. CV 85-4544 DMG(AGRx) (C.D. Cal. July 24, 2015), http://graphics8.nytimes.com/packages/pdf/us/FloresRuling.pdf [http://perma.cc/8XUM-T2NQ]. DHS responded by releasing more mothers and children, lowering bonds, and many of the mothers from the facilities were fitted with ankle monitors. US Officials Ask Judge Not to End Immigrant Family Detention, N.Y. TIMES (Aug. 7, 2015, 11:07 A.M. E.D.T.), http://www.nytimes.com/aponline/2015/08/07/us/ap-usimmigration-family-detention.html. While Judge Dee's order is a step toward strengthening the provisions of the FSA, it is still uncertain as to the long-term impact the order will have. See id. As of August 2015, over 170 House Democrats have urged the closure of the family detention facilities, and two complaints filed by immigrant rights advocates demand an immediate investigation of the facilities. Id.

${ }^{78}$ Lopez, supra note 65 , at 1644.

79 8 C.F.R. $\$ 236.3$ (2015); 8 C.F.R. $§ 1236.3$ (2015).

${ }^{80} 8$ C.F.R. § 236.3(d) (2015).
} 
While the codified sections of the FSA provide important protections for unaccompanied minors, the remaining uncodified sections of the agreement are left to the discretion of DHS authorities. ${ }^{81}$ In order to prevent future mistreatment and abuse of unaccompanied minors, the United States must take steps to see that the obligations under the FSA are fulfilled. ${ }^{82}$

\section{B. The Convention on the Rights of the ChiLd \& ThE “Best Interest of The}

\section{CHILD” PRINCIPLE}

International law also plays an important role in the United States' obligations to unaccompanied children. ${ }^{83}$ The United States signed the Convention on the Rights of the Child on February 16, $1995 .{ }^{84}$ The United States and Somalia are the only two nations in the world that have not ratified the Convention and are, therefore, not bound by its terms. ${ }^{85}$ One of the reasons for the United States' refusal to ratify the Convention is its fear of potential encroachment on parental rights. ${ }^{86}$ Constitutional lawyer and president of ParentalRights.org Michael P. Farris was quoted by The Washington Post stating, "The chief threat posed by the CRC is the denial of American self-government in accord with our constitutional processes." 87

\footnotetext{
${ }^{81}$ NAT'L IMMIGRANT JUST.CTR., supra note 69; Lopez, supra note 65, at 1644.

${ }^{82}$ Lopez, supra note 65, at 1644.

${ }^{83}$ Statement of the American Immigration Lawyers Ass'n., supra note 2.

${ }_{85}^{84} \mathrm{CRC}$, supra note 14.

85 Convention on the Rights of the Child: Frequently Asked Questions, UNICEF, http://www.unicef.org/crc/index_30229.html [http://perma.cc/H68J-ZYBN] (last updated Nov. 30, 2005).

${ }^{86}$ D. Kelly Weisberg \& Susan Frelich APPleton, Modern Family LaW CASES and Materials 872 (5th ed. 2013). Another reason for the United States' refusal to ratify is that it is not in full compliance with Article 37 of the Convention that prohibits sentencing children under eighteen years old to death or life imprisonment; See also Richard C. Dieter, The US. Death Penalty and Int'l Law: US. Compliance with the Torture and Race Conventions, DEATH PENALTY INFO. CTR. (Nov. 12, 1998), http://www.deathpenaltyinfo.org/us-death-penalty-and-international-law-uscompliance-torture-and-race-conventions [http://perma.cc/2YYD-BQRY].

${ }^{87}$ Karen Attiah, Why Won't the US. Ratify the U.N.'s Child Rights Treaty, Wash. Post (Nov. 21, 2014), http://www.washingtonpost.com/blogs/post-partisan/wp/2014/11/21/why-wont-the-u-s-ratify-the-u-n-s-child-rightstreaty/ [http://perma.cc/KT3Y-3ZUL].
} 
In order to understand the significance of the United States' refusal to ratify the CRC, it is important to note the distinction between signature and ratification. ${ }^{88}$ When a State signs a treaty it "is obliged to refrain, in good faith, from acts that would defeat the object and purpose of the treaty." ${ }^{\circ 9}$ A signature alone does not signify consent to be bound nor does it require that the State later ratify the treaty. ${ }^{90}$ The treaty only takes on a binding nature once a State has ratified it. ${ }^{91}$

Ratification, as opposed to signature, "signifies an agreement to be legally bound by the terms of the Convention." ${ }^{92}$ Although the process for ratification varies by country, it generally involves a two-step process. ${ }^{93}$ The first-step of the process involves the country reviewing the terms of the Convention to determine whether or not the terms conflict with existing domestic laws. ${ }^{94}$ If there are no conflicting provisions then the State incorporates the treaty into domestic law via domestic constitutional procedures. ${ }^{95}$ Second, the document of ratification is forwarded in a formal sealed letter to the United Nations Secretary-General located in New York. ${ }^{96}$

\footnotetext{
${ }^{88}$ EU Member States Signing and Ratifying a Treaty, CTR. FOR BIOMEDICAL ETHICS AND L., http://europatientrights.eu/countries/signing_and_ratifying_a_treaty.html [http://perma.cc/WD5R-V3R7] (last visited Jan. 25, 2015).

${ }^{89} \mathrm{Id}$. ("'Signature' is a process that has different legal meanings depending on the circumstances in which it is performed. A distinction is made between "simple signature", which is subject to ratification, and "definitive signature", which is not subject to ratification. The "simple signature" applies to most multilateral treaties. This means that when a State signs the treaty, the signature is subject to ratification, acceptance or approval. The State has not expressed its consent to be bound by the treaty until it ratifies, accepts or approves it."). The United States' "signature" on the CRC was a "simple signature" and therefore requires further ratification for the United States to be bound by the terms of the CRC. See id.

${ }^{90} \mathrm{Id}$.

${ }^{91}$ Signature, Ratification and Accession, UNICEF, http://www.unicef.org/crc/index_30207.html [http://perma.cc/5ZQ2-A9NF] (last updated May 19, 2014).

${ }^{92} \mathrm{Id}$.

${ }^{93} \mathrm{Id}$.

${ }^{94} \mathrm{Id}$. ("The formal procedures for ratification or accession vary according to the national legislative requirements of the State. Prior to ratification or accession, a country normally reviews the treaty to determine whether national laws are consistent with its provisions and to consider the most appropriate means of promoting compliance with the treaty.")

${ }^{95}$ Id. ("Most commonly, countries that are promoting the Convention sign shortly after it has been adopted. They then ratify the treaty when all of their domestically required legal procedures have been fulfilled. Other States may begin with the domestic approval process and accede to the treaty once their domestic procedures have been completed, without signing the treaty first.")

${ }^{96} I d$.
} 
Although the United States has not ratified the Convention, it could be argued that the expansive international acceptance has allowed the Convention to rise to the level of customary international law. ${ }^{97}$ Customary international law is a term of art used to describe a type of law that arises from the particular practices that States engage in "from a sense of legal obligation."98 Customary international law has both an objective element of "general practice" and a subjective element of "general acceptance," or opinio juris. 99 "Opinio juris denotes a subjective obligation, a sense on behalf of a state that it is bound to the law in question." 100 The fact that every country in the world has signed the CRC and almost every country has ratified it provides strong support that the CRC has reached the level of customary international law and is therefore binding on the United States. ${ }^{101}$

It may also be argued, however, that the United States is a persistent objector to the terms of the CRC and is therefore not bound to the terms of the Convention. ${ }^{102}$ Under international law, States become bound to customary law through actions of assent on the global stage. ${ }^{103}$ In the alternative, a State may oppose customary law in a similar manner. ${ }^{104}$ Just as States may refuse to

\footnotetext{
${ }^{97}$ How Children's Voices are Heard in Child Protective Proceedings, YALE L. SCH. (last modified December 2005), http://www.law.yale.edu/rcw/rcw/jurisdictions/am_n/usa/united_states/frontpage.htm [http://perma.cc/388U-5BF3] ("Although the United States has not yet ratified the Convention on the Rights of the Child, the convention nevertheless creates duties for the United States in two ways. First, as a signatory to the convention, the United States is bound not to contravene the object and purpose of the convention. In addition, American courts have just begun to examine whether or not the Convention on the Rights of the Child constitutes customary international law, binding the United States despite its failure to ratify the convention. The broad consensus concerning the rights of the child codified in the CRC, evidenced by the universality of its signatures and the near universality of its ratifications, suggests to many observers that these rights are quintessential customary international law.").

98 JEFFREY L. DUNOFF ET AL., INT'L LAW NORMS, ACTORS, PROCESS A PROBLEM-ORIENTED APPROACH 77-9 (3d ed. 2010).

${ }^{99} I d$.

${ }^{100}$ Opinio juris, LEGAL INFO. INST., https://www.law.cornell.edu/wex/opinio_juris_international_law [http://perma.cc/V2WX-AFJR] (last visited March 13, 2015).

${ }^{101}$ YALE L. SCH., supra note 97.

${ }^{102}$ UNICEF, supra note 91.

${ }^{103} I d$.

${ }^{104} I d$.
} 
ratify a treaty or later withdraw from a treaty that they have signed, States may also take actions to avoid becoming bound by customary law. ${ }^{105}$ States that act publicly in an attempt to show their objection to customary international law are said to be persistent objectors. ${ }^{106}$ According to the rule of the persistent objector, "a state that has persistently objected to a rule of customary international law during the course of the rule's emergence is not bound by the rule." 107

Despite the United States' potential status as a persistent objector, a study completed by Yale Law School noted that the CRC, even if found to be nonbinding, creates duties for the United States for the following two reasons. ${ }^{108}$ First, Article 18 of the Vienna Convention on the Law of Treaties provides: "A State is obliged to refrain from acts which would defeat the object and purpose of a treaty when: (a) It has signed the treaty ... until it shall have made its intentions clear not to become a party to the treaty." ${ }^{109}$ Second, the United States' courts have provided analysis of the extent that the CRC fulfills the role of customary international law. ${ }^{110}$ Specifically, in Beharry v. Reno, the court opined that "given its widespread acceptance, to the extent that it acts to codify longstanding, widely-accepted principles of law, the CRC should be read as customary international law." ${ }^{111}$ Although this remark by the court was not part of its holding, it nevertheless provides support of how the court analyzes and views the CRC. ${ }^{112}$

Additionally, the actions of the United States in adopting provisions of the CRC for its own domestic law provide support that the provisions of the CRC have risen to the level of customary

\footnotetext{
105 Ted L. Stein, The Approach of the Different Drummer: The Principle of the Persistent Objector in International Law, 26 Harv. Int'l. L.J. 457 (1985).

${ }^{106} I d$.

${ }^{107} I d$.

${ }^{108}$ YALE L. SCH., supra note 97.

${ }^{109}$ Vienna Convention on the Law of Treaties, art. 18, opened for signature May 23, 1969, 1155 U.N.T.S. 331 (entered into force Jan. 27, 1980); YALE L. SCH., supra note 97.

${ }^{110}$ YALE L. SCH., supra note 97.

${ }^{111}$ Beharry v. Reno, 183 F. Supp.2d 584, 601 (E.D. N.Y. 2002); YALE L. SCH., supra note 97.

${ }^{112} I d$.
} 
international law. Art. 3, one of the main sections of the CRC, provides in clause 1 that "[i]n all actions concerning children, whether undertaken by public or private social welfare institutions, courts of law, administrative authorities or legislative bodies, the best interests of the child shall be a primary consideration." 113 This provision of the CRC has become known as the "best interest of the child" principle, and it plays a central role within the domestic sphere of the United States. ${ }^{114}$ The principle is used to refer to the factors that the courts must take into consideration when determining what actions are appropriate for the care, protection and well-being of children in domestic child welfare cases. ${ }^{115}$ The principle does not, however, fully extend to the sphere of immigration law. ${ }^{116}$ By failing to incorporate the "best interest of the child" principle into the sphere of immigration law, the United States is essentially ignoring not only international law but also its own domestic law. ${ }^{117}$ The "best interest of the child" principle should be applied to all children within the U.S. immigration system, as it would ensure that the children are treated humanely. ${ }^{118}$

\section{The Convention Relating to the Status of Refugees}

Another important international agreement that has an impact on the United States' obligations in regard to unaccompanied minors is the Convention Relating to the Status of

${ }^{113}$ CRC, supra note 14 , art. 3.

114 Child Welfare Info. Gateway, Determining the Best Interest of the Child 1-2 (2012), https://www.childwelfare.gov/systemwide/laws_policies/statutes/best_interest.pdf\#Page=1\&view=Fit [http://perma.cc/JHZ8-DFAK] [hereinafter CHILD WELFARE].

${ }^{115} I d$. at 2.

${ }^{116}$ Amanda Levinson, Unaccompanied Immigrant Children: A Growing Phenomenon With Few Easy Solutions, MIGRATION POL'Y INST., http://www.migrationpolicy.org/article/unaccompanied-immigrant-children-growingphenomenon-few-easy-solutions [http://perma.cc/N9N8-9AJL] (Jan. 24, 2011). The reason that the "best interest of the child" principle is not fully integrated into the U.S.' immigration system is that for many years there was a lack of distinction between adults and children, leaving children to be shuffled through the system as if they were adults. Id. The landscape of U.S. immigration began to change with the 1993 Flores v. Reno case. Id.

${ }^{117}$ See id.

${ }^{118} I d$. 
Refugees ("CRSR"). ${ }^{119}$ The CRSR came into force on April 22, 1954, and has its foundation in Article 14 of the Universal Declaration of Human Rights (“UDHR”). ${ }^{120}$ The CRSR was created during a time of war when there was an estimated 1 million refugees in search of refuge. ${ }^{121}$ The Convention was formed with the objective of providing protection to those who had experienced human rights violations. ${ }^{122}$ Article 14 of the UDHR provides that "everyone has the right to seek and enjoy in other countries asylum from persecution." ${ }^{\text {"23 }}$ The United States did not sign the initial version of the CRSR, but in 1968 it ratified the amended version of the Convention known as the 1967 UN Protocol relating to the Status of Refugees ("Protocol"). ${ }^{124}$ The Protocol adjusted the temporal limitations for when an individual could be considered a refugee by removing the "before 1951" language. ${ }^{125}$

Another important point is the strong relationship between the language of Article 1 of the CRSR and United States’ asylum provisions of $\S \S 101(\mathrm{a})(42)(\mathrm{A})$ and 208 of the Immigration and Nationality Act ("INA"). ${ }^{126}$ The INA $\S 241(\mathrm{~b})(3)(A)$ regarding the mandatory withholding of deportation and Article 33 of the CRSR also use almost identical language to describe when a refugee may not be returned to his or her home State. ${ }^{127}$ The United States expressed its intent to

\footnotetext{
${ }^{119}$ Statement of the American Immigration Lawyers Ass'n, supra note 2.

${ }^{120}$ Introductory Note by the Office of the United.Nations High Commissioner for Refugees to the Text of the 1951 Convention Relating to the Status of Refugees, http://www.unhcr.org/3b66c2aa10.html [http://perma.cc/NP36$\mathrm{X} 3 \mathrm{BG}]$ [hereinafter Introductory Note].

121 The Rights of Refugees, THE U.N. REFUGEE AGENCY, http://www.unhcr.org/pages/4ab388876.html [http://perma.cc/5LVF-4CXG] (last visited May 13, 2015).

${ }^{122} \mathrm{Id}$.

${ }^{123}$ Convention Relating to the Status of Refugees, art. 14(1), opened for signature July 28, 1951, 189 U.N.T.S. 137 (entered into force April 22, 1954).

${ }^{124}$ Joan Fitzpatrick, The International Dimension of US. Refugee Law, 15 BERKELEY J. OF INT'L L. 1 (1997); see also 1967 Protocol.

${ }^{125}$ Introductory Note, supra note 120.

${ }^{126}$ Fitzpatrick, supra note 124 , at 1-2.

${ }^{127} \mathrm{Id}$.
} 
be bound and adhere to internationally set obligations when dealing with refugees, by ratifying the Protocol and transposing the CRSR into its domestic immigration laws. ${ }^{128}$

The Convention, along with the Protocol, provide the international rules States must follow regarding the status, treatment, and protection of refugees. ${ }^{129}$ A refugee is defined by the Convention as a person who:

$[\mathrm{O}]$ wing to a well-founded fear of being persecuted for reasons of race, religion, nationality, membership of a particular social group or political opinion, is outside the country of his nationality and is unable or, owing to such fear, is unwilling to avail himself of the protection of that country; or who, not having a nationality and being outside the country of his former habitual residence as a result of such events, is unable or, owing to such fear, is unwilling to return to it. ${ }^{130}$

An individual must fit the above definition of a refugee in order to receive international protection. ${ }^{131}$ The unaccompanied children fleeing Mexico, Honduras, Guatemala, and El Salvador are likely considered refugees, because the governments in their home countries are either unable to provide or have refused to provide protection of their basic human rights. ${ }^{132}$ Under the Convention and the Protocol, an individual who falls under the definition of a refugee is in turn afforded special protections. ${ }^{133}$ Those protections specifically include the obligation to not return a refugee to a country where he or she would be subjected to death. ${ }^{134}$

Unfortunately, the United States has failed to adhere to the obligations set forth under the Convention and Protocol. ${ }^{135}$ The DHS has increasingly used expedited removal proceedings, a

\footnotetext{
${ }^{128} \mathrm{Id}$.

${ }^{129}$ Introductory Note, supra note 120.

${ }^{130}$ Convention Relating to the Status of Refugees, supra note 123, art. 1(A)(2).

${ }^{131}$ CHILDREN ON THE RUN, supra note 20, at 8.

${ }^{132}$ Id.at $9-11$.

133 Id. at 8.

${ }^{134} \mathrm{Id}$.

${ }^{135}$ See Statement of the American Immigration Lawyers Association, supra note 2.
} 
process that will be explained in detail later in this Note, to return the unaccompanied minors back to the turmoil of their countries of origin. ${ }^{136}$ Moreover, the unaccompanied minors are not provided with any type of legal representation, which only serves to aggravate their already dire and vulnerable circumstances. ${ }^{137}$

\section{Comparative Analysis of the CurRent Policies of the United States}

\section{WITH SWEDEN AND THE UNITED KINGDOM}

\section{A. United STATES}

Historically, the United States has not made special provisions for children within its immigration system and has basically treated children in the same manner as adults. ${ }^{138}$ The approach of the U.S. immigration system conflicts with its family law system, which focuses on the "best interest of the child" principle. ${ }^{139}$ Although the special status of children is now taken into consideration by the U.S. immigration system, the system is often still found to fall short of the "best interests of the child." 140

When unaccompanied minors are caught crossing the border they are often detained and remain in the custody of Border Patrol officials. ${ }^{141}$ Children from Mexico and Canada "must be screened by CBP officers to determine if each child is unable to make independent decisions, is a victim of trafficking, or fears persecution in his home country." ${ }^{142}$ If a child does not meet one of the aforementioned requirements, he or she will be immediately returned to their country of

\footnotetext{
${ }^{136}$ See id.

${ }^{137}$ Id.

${ }^{138}$ Levinson, supra note 116.

${ }^{139}$ Id.

${ }^{140}$ See HalfWAY HoME, supra note 1, at 14.

141 Why are so Many Children Trying to Cross the US Border?, BBC News U.S. \& CAN., (Sept. 30, 2014), http://www.bbc.com/news/world-us-canada-28203923 [http://perma.cc/5QXK-9P2L].

${ }^{142}$ Children in Danger: A Guide to the Humanitarian Challenge at the Border, IMMIGR. POL'Y CTR. (July 10, 2014), http://www.immigrationpolicy.org/special-reports/children-danger-guide-humanitarian-challenge-border [http://perma.cc/YK49-VNG7].
} 
origin. ${ }^{143}$ Some non-governmental actors argue that the CBP is not the correct agency to screen children. $^{144}$

The Department of Homeland Security transfers the unaccompanied minors who are allowed to remain in the United States, while their court case proceeds, to Health and Human Services within 72 hours of apprehension. ${ }^{145}$ As previously discussed, the Department of Unaccompanied Children's Services ("DUCS"), created by the Office of Refugee Settlement ("ORR"), contracts with private facilities to provide the needed services and care to unaccompanied minors. ${ }^{146}$

For children with family located in the United States, the Flores Settlement Agreement provides a general policy favoring the release of unaccompanied minors in custody to a parent or guardian. ${ }^{147}$ Under Section VI General Policy Favoring Release, the Flores Settlement Agreement states as follows:

Where the INS determines that the detention of the minor is not required either to secure his or her timely appearance before the INS or the immigration court, or to ensure the minor's safety or that of others, the INS shall release a minor from its custody without unnecessary delay. ${ }^{148}$

The release to a parent or other legal guardian prevents the child from remaining in a detention center, a setting which may cause additional trauma for the unaccompanied minor. ${ }^{149}$ The person

\footnotetext{
${ }^{143} I d$.

${ }^{144}$ Id. ('Non-governmental organizations (NGOs) have expressed concern that CBP is the 'wrong agency' to screen children for signs of trauma, abuse, or persecution. Appleseed issued a report that stated 'as a practical matter,' CBP screening 'translates into less searching inquiries regarding any danger they are in and what legal rights they may have.' Appleseed also expressed concern that the U.S.-Mexico repatriation agreement has been geared towards 'protocols of repatriations logistics,' rather than best practices for child welfare.").

145 BBC NEWS U.S. \& CAN., supra note 141.

146 HALFWAY HOME, supra note 1 , at 4.

${ }^{147}$ Flores Settlement Agreement, supra note 13.

${ }^{148} \mathrm{Id}$.

${ }^{149}$ IMMIGR. POL'Y CTR., supra note 142.
} 
to whom the child is released is responsible to see that the child attends all immigration hearings and proceedings. ${ }^{150}$

The United States has historically not provided any type of guardian ad litem or social representative to be appointed to oversee that the rights of the child are fulfilled. ${ }^{151}$ Furthermore, children, like adults within the immigration system, are not provided any type of legal counsel. ${ }^{152}$ The Immigration and Naturalization Act provides that government funding should not be used to provide legal counsel for persons in removal proceedings. ${ }^{153}$ The lack of access to legal representation and services that provide an explanation to children of their rights only increases their vulnerability. ${ }^{154}$ "UNHCR and many U.S.-based groups that monitor U.S. refugee and asylum practices have cautioned that concerns over illegal immigration should not trump the United States' international obligations to protect those fleeing persecution or other harm."155 Without adequate protections, children become lost in the United States' complex removal system. ${ }^{156}$

\section{B. SWEDEN}

All European Union ("EU”) Member States have ratified the CRC. ${ }^{157}$ The greatest distinction of the EU system from the U.S. system is in its application of the "best interests of the

\footnotetext{
${ }^{150} \mathrm{Id}$.

${ }^{151} \mathrm{Id}$. In order to fulfill its duties under the statute, ORR created the Unaccompanied Children Program ("UAC Program"). See Linda Kelly Hill, The Right to Be Heard: Voicing the Due Process Right to Counsel for Unaccompanied Alien Children, 31 B.C. Third World L.J. 41, 48 (2011). Due to a lack of funding, the program has helped less than half of all unaccompanied minors. Id. at 49-50. The UAC Program will be discussed in more detail later in this Note.

152 IMMIGR. POL'Y CTR., supra note 142.

153 8 U.S.C. $\$ 1362$ (2006) ("In any removal proceedings before an immigration judge and in any appeal proceedings before the Attorney General from any such removal proceedings, the person concerned shall have the privilege of being represented (at no expense to the Government) by such counsel, authorized to practice in such proceedings, as he shall choose.").

154 Statement of the American Immigration Lawyers Association, supra note 2.

155 IMMIGR. POL'Y CTR., supra note 142.

156 See id.

${ }^{157}$ CRC, supra note 14.
} 
child" principle within the realm of immigration. ${ }^{158}$ In some EU Member States, children are appointed a guardian ad litem if the child is without a legal guardian. ${ }^{159}$ Other EU Member States provide the child with other forms of representation such as a social worker. ${ }^{160}$ Unaccompanied minors in the EU are only placed in detention if no other options exist, and they are provided with legal counsel. Furthermore, children are only returned to their home country "as a last resort and only if it is in their best interest."

Given the variation of approaches among EU Member States, this Note will specifically focus on Sweden's and the UK's approaches to unaccompanied minors, as these two Member States have had success in creating a more humane system for dealing with unaccompanied minors. Sweden receives more unaccompanied minors seeking asylum than any other country in the EU. ${ }^{162}$ Sweden, similar to the United States, has experienced a large increase in the number of unaccompanied minors entering its borders. ${ }^{163}$ In 2014, approximately 7,000 unaccompanied children arrived to Sweden, which is double the number of $2013 .{ }^{164}$

When an unaccompanied minor arrives in Sweden, the Migration Board is the government body in charge of seeing that the minor is placed in one of the nine receiving municipalities. ${ }^{165}$ In

\footnotetext{
${ }^{158}$ Levinson, supra note 116.

${ }^{159} \mathrm{Id}$.

${ }^{160} \mathrm{Id}$.

${ }^{161} \mathrm{Id}$.

162 Policies, practices and data on unaccompanied minors in 2014-Sweden, EUROPEISKA MIGRATIONSNÄTVERKET, http://www.europarl.europa.eu/meetdocs/2014_2019/documents/libe/dv/16_swedish_case_factsheet_/16_swedish_c ase_factsheet_en.pdf [http://perma.cc/B75A-LPPG] (last visited Aug. 24, 2015).

${ }^{163}$ Lone child migrants to Sweden double in 2014, THE LOCAL (Jan. 2, 2015), http://www.thelocal.se/20150102/lonechild-migrants-double-in-2014 [http://perma.cc/7QML-55K7].

${ }^{164} I d$.

165 Anna Lundberg \& Lisa Dahlquist, Unaccompanied Children Seeking Asylum in Sweden: Living Conditions from a Child-Centred Perspective, 31 REFUGEE SURV. Q. 54, 56 (2012). "These are municipalities that are in geographical proximity to the main cities of arrival, namely Malmo, Stockholm, and Gothenburg. Here the children live in temporary housing, commonly referred to as transit housing. The child stays in the transit housing until a place has been found in one of the assigned municipalities that the Swedish Migration Board has entered into an agreement with on longer term housing." Id.
} 
most cases, the Migration Board also appoints legal counsel for the child. ${ }^{166}$ Before being transferred to the municipalities, the children are placed in temporary housing. ${ }^{167}$ The child remains in the temporary housing, until a long-term placement is established in one of the municipalities. ${ }^{168}$ The municipality is responsible for the child's care and wellbeing while the child awaits a decision regarding his or her asylum application by the Migration Board. ${ }^{169}$ The Social Welfare Board located in the municipality where the child has been placed is responsible for the placement of children. ${ }^{170}$ Children are often placed in municipality accommodations centers located near the city center, schools, and other public and social service agencies. ${ }^{171}$ Staff members who have received some form of social work training oversee the center, and the children have access to common social areas where they can watch television and interact with other children. ${ }^{172}$

In addition to providing housing, the municipality is responsible for appointing a legal guardian. ${ }^{173}$ The legal guardian, sometimes referred to as a "deputy parent," is responsible for acting as both a guardian and a custodian of the child. ${ }^{174}$ The main duty of the legal guardian is to ensure that the decisions made on behalf of the child by the municipality are in the child's best interest. ${ }^{175}$

\footnotetext{
${ }^{166} \mathrm{Id}$. at 57.

${ }^{167} I d$. at 56.

${ }^{168} \mathrm{Id}$.

${ }^{169} I d$. at 58 .

${ }^{170} I d$. at 59.

${ }^{171}$ U.N. High COMM'R FOR REFugees Regional OFF. FOR THE BALTIC AND NORDIC COUNTRIES, Voices OF AFGHAN CHILDREN- A STUDY OF ASYLUM-SEEKING CHILDREN IN SWEDEN 52 (June 2010), http://www.unhcr.org/4c8e24a16.pdf [http://perma.cc/U3FH-WE9N] [hereinafter VOICES OF AFGHAN CHILDREN].

${ }^{172} I d$.

${ }^{173}$ Lundberg \& Dahlquist, supra note 165, at 58.

${ }^{174} I d$.

${ }^{175} I d$.
} 
In Sweden, detention of children is only used as a last resort. ${ }^{176}$ A detention order "may only be used if there is reason on account of the alien's personal situation or other circumstances to assume that the alien may otherwise go into hiding or pursue criminal activities in Sweden."177 Other protections afforded unaccompanied minors in Sweden include the right to school and health care. ${ }^{178}$ Unaccompanied minors are afforded the right to receive an education at the school located within the municipality where they are placed. ${ }^{179}$ Moreover, children have the same right to healthcare as Swedish children, and the county councils receive reimbursement from the Government for providing healthcare. ${ }^{180}$

The Swedish immigration system for unaccompanied minors is focused and driven by the protection of the child. ${ }^{181}$ Children within the system are generally found to be content with the accommodations they are afforded. ${ }^{182}$ A criticism of the Swedish immigration system, along with the immigration systems of other EU Member States, is that they are too lenient and in turn encourage illegal immigration. ${ }^{183}$ Nevertheless, the Swedish system for handling unaccompanied minors provides more protections to children who are in vulnerable situations. ${ }^{184}$

\section{UNITED KINGDOM}

\footnotetext{
176 UTLÄNNINGSLAGEN [Utl] [ALIENS ACT] 10:2 (Swed.), http://www.government.se/content/1/c6/06/61/22/bfb61014.pdf.

177 Id. $10: 1$

${ }^{178}$ Lundberg \& Dahlquist, supra note 165, at 59.

${ }^{179} \mathrm{Id}$.

${ }^{180} \mathrm{Id}$.

${ }^{181}$ Policies, practices and data on unaccompanied minors, supra note 162.

${ }^{182}$ Lundberg \& Dahlquist, supra note 165, at 67-72.

${ }^{183}$ Levinson, supra note 116.

${ }^{184}$ Lundberg \& Dahlquist, supra note 165, at 72.
} 
In 2012, the UK received approximately 1,200 unaccompanied minors who sought asylum. ${ }^{185}$ Local authorities cared for an additional 2,150 unaccompanied minors. ${ }^{186}$ Struggling to adequately care for the unaccompanied minors, the UK was often found to place a higher importance on immigration regulations than on the best interest of the children. ${ }^{187}$ In 2013 , the UK's Joint Committee on Human Rights (“JCHR”) urged the State to make changes. ${ }^{188}$ The report of the JCHR noted, "[p]roviding protection and support effectively is crucial: the asylum and immigration process can be complex, and the stress it can cause can be particularly acute for children."189

In an attempt to improve the system in place, the UK introduced new immigration rules that provide a framework based on the best interests of children. ${ }^{190}$ When an unaccompanied minor arrives in the UK, he or she is the responsibility of the local social services department in the area where the minor is located. ${ }^{191}$ After completing an assessment, the social service center provides needed services to the child. ${ }^{192}$ Children under the age of sixteen are placed in some type of foster care, whereas children over the age of sixteen are place in some type of independent living facility that provides supervised accommodation. ${ }^{193}$ Additionally, the local social service authority will

\footnotetext{
${ }^{185}$ Amelia Gentleman, Children seeking asylum should 'be better cared for' by the state, THE GUARDIAN (June 11, 2013), http://www.theguardian.com/uk/2013/jun/12/children-seeking-asylum-better-care [http://perma.cc/KM4J$\mathrm{JC} 9 \mathrm{~F}]$. https://www.gov.uk/government/uploads/system/uploads/attachment_data/file/279104/UnaccompaniedMigrantMino rs.pdf [http://perma.cc/FWY6-CXZD] [hereinafter HUMAN RIGHTS].

${ }^{191}$ Katia Bianchini, Unaccompanied asylum-seeker children: flawed processes and protection gaps in the UK, FORCED MigRATION REV. (Mar. 2011), http://www.fmreview.org/en/non-state/52-53.pdf [http://perma.cc/5JLLEW9W].

${ }^{192} I d$.

${ }^{193} I d$.
} 
oversee the care and treatment of the child "on a regular basis to ensure that the child's needs are being met."194

The UK's Secretary of State Report for 2014 provided additional recommendations to further improve the system in place. ${ }^{195}$ The following statement was included among the recommendations:

We recommend that the Government work with child welfare and safeguarding experts to develop a specific training programme to improve awareness and understanding of the UNCRC and its application to unaccompanied migrant children, particularly with respect to properly considering children' s best interests. Such a programme, delivered by external providers, should be rolled out first to staff in frontline immigration and asylum roles, and to those in local authorities that deal regularly with unaccompanied migrant children. The programme should then be rolled out more widely as resources allow. 196

The UK's Secretary of State Report also includes recommendations that the Government create a more defined role for the Children's Champion, “confirming that it is invested with a proactive duty of care to ensure that the agency meets its international and domestic obligations . ..." 197 The role of the Children's Champion is provided for under section 55 of the Borders Citizenship and Immigration Act of 2009:

2.9 There shall be a senior member of staff (the "Children's Champion") who is responsible to the Chief Executive of the UK Border Agency for promoting the duty to safeguard and promote the welfare of children throughout the UK Border Agency, for offering advice and support to UK Border Agency staff in issues related to children, and identifying and escalating issues of concern. ${ }^{198}$

\footnotetext{
${ }^{194} I d$.

195 HUMAN RIGHTS, supra note 190, at 2-23. The U.K.'s Secretary of State of the Home Department is responsible for overseeing the areas of security and terrorism, legislative programme, and expenditure issues in the U.K. as a whole. Secretary of State for the Home Department, GoV. U.K., https://www.gov.uk/government/ministers/secretary-of-statefor-the-home-department [http://perma.cc/E24B-ZVT6] (last visited Aug. 23, 2015).

196 HuMAN RIGHTS, supra note 190, at 6.

197 Id. at 7.

${ }^{198} I d$. at 7-8. ("As the guidance makes clear, the primary responsibility for ensuring that the business meets its obligations in respect of children rests with senior managers in the business. The Children's
} 
Just as the United States, both Sweden and the UK have experienced similar issues with the arrival of unaccompanied minors and both countries have created uniquely tailored solutions to address the issues. ${ }^{199}$ Although neither the approach of Sweden or the UK is completely flawless nor easily transferable to the United States, they each provide meaningful contributions as to how to best address the issues associated with unaccompanied minors.

\section{Recommendations: The Changes the United States Should Make to COME INTO COMPLIANCE WITH ITS OBLIGATIONS}

In order for the United States to come into compliance with its international and domestic obligations, it must make significant changes in the way it addresses the situation of unaccompanied minors. The following section of this Note will discuss several important steps the United States should take, in order to properly address the shortfalls of the current immigration system for handling unaccompanied minors. Specific changes that must be made for the United States to come into compliance with its obligations include codification of the Flores Settlement Agreement,${ }^{200}$ ratification of the Convention of the Rights of the Child, ${ }^{201}$ and a detention system with a focus on the "best interest of the child" principle. Additionally, the United States should provide meaningful access to legal counsel and decrease the use of expedited removal. Finally, the United States must take foreign policy initiatives to address the reasons why the children are fleeing their countries of origin.

\section{A. FulfiLlment ANd CodificAtion of the FLores Settlement AgREement}

Champion is there to offer support, guidance and challenge, including heading up the network of senior children's leads. The Children's Champion is supported in this role by the Office of the Children's Champion which includes two senior social workers with extensive experience in the UK and internationally.")

${ }^{199}$ Levinson, supra note 116.

${ }^{200}$ Flores Settlement Agreement, supra note 13.

${ }^{201}$ CRC, supra note 14 , art. 3. 
As previously mentioned, some sections of the FSA have been codified, allowing for more successful enforcement. ${ }^{202}$ While the codified sections of the FSA provide important protections for unaccompanied minors, the remaining uncodified sections of the agreement are left to the discretion of DHS authorities. ${ }^{203}$ In order to prevent future mistreatment and abuse of unaccompanied minors, the United States must take steps to see that the obligations under the FSA are fulfilled. ${ }^{204}$

The Department of Homeland Security is bound to comply with the FSA. ${ }^{205}$ Nevertheless, breaches of the FSA terms continue to surface, given the lack of oversight and enforcement mechanisms to ensure that DHS maintains compliance. ${ }^{206}$ Failure of DHS to comply, along with the lack of enforcement mechanisms, stems from the fact that the agreement itself does not provide any type of constitutional right for minors. ${ }^{207}$

In Walding v. United States, several unaccompanied minors filed suit against federal officials for abuses they endured while at the Nixon facility ${ }^{208}$ that violated the terms of the Flores Settlement Agreement. ${ }^{209}$ In the Complaint, the "Plaintiffs allege[d] that '[a]ll Defendants knew and/or should have known and/or were deliberately indifferent to the rampant physical and sexual abuse of the Plaintiffs at the Nixon facility." 210 The claim was asserted on the foundation "that the provisions of the Flores Agreement created liberty and property interests protected by the Due

\footnotetext{
202 NAT'L IMMIGRANT JUST. CTR., supra note 69, at 1.

${ }^{203}$ NAT'L IMMIGRANT JUST. CTR., supra note 69, at 2; Lopez, supra note 65, at 1644-45.

${ }^{204}$ Lopez, supra note 65, at 1645-46.

205 NAT'L IMMIGRANT JUST. CTR., supra note 69.

${ }^{206}$ Lopez, supra note 65, at 1644.

${ }^{207}$ See Walding v. U.S., No. SA-08-CA-124-XR, 2009 U.S. Dist. LEXIS 116932, at*12 (W.D. Tex. Dec. 15, 2009).

${ }^{208}$ Susan Carroll, Unaccompanied children in country illegally still lack federal protection, HoUS. CHRON. (May 29, 2014), http://www.houstonchronicle.com/news/houston-texas/houston/article/Unaccompanied-children-in-countryillegally-still-5514344.php [http://perma.cc/Q5QD-5346] (“ORR pulled the children out of Nixon after the worker's arrest and pledged reforms, including creating a "zero tolerance" policy for abuse. Brané, with the Women's Refugee Commission, said her concerns about the handling of abuse allegations deepened after the Nixon shelter shut down."). ${ }^{209}$ Walding v. U.S., No. SA-08-CA-124-XR, 2009 U.S. Dist. LEXIS 116932, at*12 (W.D. Tex. Dec. 15, 2009).

${ }^{210} \mathrm{Id}$. at 5.
} 
Process Clause of the Fifth Amendment, and thus due process was violated when the Flores Agreement's provisions were violated." 211 In the court's reasoning, it "noted that it was apparently undisputed that the Flores settlement agreement, which is in effect a remedial decree, does not in and of itself confer any constitutional rights upon the plaintiffs, and that Fifth Circuit case law is clear that remedial decrees confer no such rights." ${ }^{212}$

Because the plaintiffs were unable to establish a deprivation of an established protected right under the Flores Settlement Agreement, the court found that it was unable to interfere with the "officials" discretion." ${ }^{.13}$ The court went on further to explain the following:

The Agreement's intent was to create minimum guidelines and requirements regarding the minors' conditions of confinement to try to ensure their well-being and safety, and it does not purport to guarantee prevention of the episodic acts of abuse by program staff such as occurred here. The Court concluded that the plaintiffs failed to show that they were deprived of any entitlement to "safe conditions" created by the Agreement. The Court further concluded that, even if Plaintiffs had established an entitlement protected by due process ... . the defendants would be entitled to qualified immunity because the plaintiffs' constitutional rights were not clearly established at the time. ${ }^{214}$

The unfortunate lack of constitutional protection for unaccompanied minors leaves them without any form of recourse and essentially without any protection. ${ }^{215}$ Codification of the entire Flores Settlement Agreement would not only allow for more defined standards but would also give courts the power to hold DHS accountable for shortcomings in the treatment of unaccompanied minors. ${ }^{216}$

\footnotetext{
${ }^{211} I d$. at 9.

${ }^{212} I d$. at 12 .

${ }^{213} \mathrm{Id}$. at 14 .

${ }^{214} \mathrm{Id}$. at $14-15$.

${ }^{215}$ Lopez, supra note 65, at 1669.

${ }^{216} I d$. at $1670-71$.
} 


\section{B. RATIFICATION OF THE CONVENTION OF THE RIGHTS OF THE CHILD AND}

\section{IMPLEMENTATION OF THE BEST INTEREST OF THE CHILD PRINCIPLE}

Ratification of the CRC is an important first step in securing the rights of immigrant children in the United States. ${ }^{217}$ Article 3 of the CRC provides that "[i]n all actions concerning children, whether undertaken by public or private social welfare institutions, courts of law, administrative authorities or legislative bodies, the best interests of the child shall be a primary consideration." ${ }^{218}$ Children escaping the turmoil of their home countries should be treated in a manner specifically tailored for their particular situation in an attempt to protect them from further harm. ${ }^{219}$ As provided by the American Immigration Lawyers' report: "Abuse at the hands of immigration officers and agents compounds the trauma and abuse that many of these children have already suffered." ${ }^{220}$ It is imperative that children receive humane treatment while they are within the U.S. immigration system. ${ }^{221}$ In order to achieve this goal, the CRC would provide children with the specific protection they need to ensure that their best interests are fulfilled. ${ }^{222}$

Nevertheless, the United States is hesitant to ratify the CRC and unlikely to do so any time soon. ${ }^{223}$ As previously mentioned, the United States' refusal to ratify the Convention has been attributed to the fear of potential encroachment on parental rights. ${ }^{224}$ Even if the United States does not ratify the CRC it is important for it to fulfill its obligation under the "best interests of the child"

${ }^{217}$ Kate Englund, Protecting the Human Rights of Unaccompanied Immigrant Minors, THE UNIV. OF CHI. SCH. OF SOC. SERV. ADMIN. (2011), http://ssa.uchicago.edu/protecting-human-rights-unaccompanied-immigrant-minors [http://perma.cc/V2ES-TUWF].

${ }^{218}$ CRC, supra note 14 , art. 3.

${ }^{219}$ HALFWAY HOME, supra note 1, at 1.

${ }^{220}$ Statement of the American Immigration Lawyers Association, supra note 2.

${ }^{221}$ HALFWAY HOME, supra note 1, at 1.

222 Englund, supra note 217.

${ }^{223}$ WEISBERG \& APPLETON, supra note 86 , at 872.

${ }^{224} I d$. 
principle already integrated into domestic law. ${ }^{225}$ By making the "best interest of the child" principle a priority in the care and treatment of children within the U.S. immigration system, children within the system would be treated with respect and dignity. ${ }^{226}$

Fulfillment of the "best interest of the child" principle could be achieved by incorporating aspects of the Swedish and UK systems of appointed guardian ad litems and by providing access to legal counsel. ${ }^{227}$ Because children as refugees escaping the violence of their home countries potentially qualify as asylum seekers, it is important that their claims of a well-founded fear are heard. ${ }^{228}$

Furthermore, children have a limited ability to make meaningful decisions for themselves regarding their best interests, especially in a time of crisis. ${ }^{229}$ The objectives of attorneys and DUCS staff can come into conflict, leaving the child in between competing interests. ${ }^{230}$ A guardian ad litem would play an independent role of helping to balance the objectives of the other adults involved in making decisions for the child who is attempting to navigate the complexities of the immigration process. $^{231}$

A guardian ad litem would also be able to provide important emotional support for the unaccompanied minor, as the guardian would maintain a continuous presence in the child's life. ${ }^{232}$

${ }^{225}$ Levinson, supra note 116.

${ }^{226}$ Englund, supra note 217.

${ }^{227}$ Levinson, supra note 116.

${ }^{228}$ Englund, supra note 217.

${ }^{229}$ HALFWAY HOME, supra note 1, at 23-4.

${ }^{230} I d$. at 24.

${ }^{231} I d$. ("The need for assistance from an independent adult is particularly important because of the adversarial nature of immigration proceedings and the complicated circumstances unaccompanied children face. Children come into contact with an endless number of adults, all demanding information, and all with different roles. Children in immigration proceedings often fail to understand how their experiences relate to a possible application for asylum or other legal protections to which they may be entitled. Many children have been told repeatedly by adults, family or traffickers to keep their stories secret. Further, children have no tangible way to exercise their rights under the Flores Settlement absent the assistance of an advocate.")

${ }^{232}$ Id. 
As the child is moved to another facility or receives a new attorney, the child may feel as if he or she is being shuffled through the system. ${ }^{233}$ Feeling as though he or she does not have a connection with the adults with whom the child comes in contact, the child is unlikely to express his or her concerns or needs. ${ }^{234}$ Randy's story is one example of the success that a guardian ad litem can have in providing care to an unaccompanied minor.:235

A guardian ad litem represented Randy, a child in secure custody at the Southwest Indiana Regional Youth Village in Vincennes, Indiana, where he complained of being kept in his cell for 23 hours per day. He was not given reading material, the staff did not support him and he complained of being extremely depressed and bored. Because the child had no criminal record, and was being detained under harsh and unnecessary conditions, the guardian ad litem worked on the child's behalf to argue that he was not being kept in the least restrictive setting appropriate as mandated under the Flores Settlement. Fortunately, and because of his guardian ad litem, Randy was stepped down to a less restrictive staff-secure placement within the facility. After the transfer, the guardian ad litem reported that the child's mental health and outlook had improved significantly. ${ }^{236}$

Additionally, the United States should promote the "best interest of the child" principle for unaccompanied minors by providing some type of social worker representative for children who have no family in the United States. ${ }^{237}$ The duty of the social worker, similar to the guardian $a d$ litem in the Swedish and UK systems, would insure that the child in custody is receiving the appropriate medical care, food, clothing, and other essential services. ${ }^{238}$ The protections provided to children in the domestic welfare system "that prioritize the safety, permanency, and well-being

\footnotetext{
${ }^{233}$ See id.

${ }^{234}$ See id.

${ }^{235}$ HALFWAY HOME, supra note 1, at 24.

${ }^{236} I d$.

${ }^{237}$ Englund, supra note 217.

${ }^{238}$ Id.
} 
of the child can and should be translated into work with immigrant children." ${ }^{239}$ This will ensure that children as a whole, regardless of where they are from are treated with dignity and respect. ${ }^{240}$

Moreover, for children who have no family or legal guardian to whom they can be released within the United States, it is imperative that they are placed in a less restrictive setting. ${ }^{241}$ The less restrictive setting requirement is provided for in the Flores Settlement Agreement. ${ }^{242}$ A "best interest of the child" alternative to the detention would be a more community-based system, similar to those found in Sweden. ${ }^{243}$ Instead of a focus on detention and punishment mechanisms, the facilities should provide more child friendly accommodations. ${ }^{244}$

Finally, in order to further the "best interest of the child" principle, it is important that unaccompanied minors are provided with legal counsel to ensure that the child's rights are protected throughout the immigration process. ${ }^{245}$ Unaccompanied minors, just as adults in an immigration removal proceeding, have no right to government funded legal counsel. ${ }^{246}$ "Children, even those who survived trauma or persecution or live in fear of return, are left to navigate our laws and to present their claims without any legal assistance when representation by an attorney is the 'single most important factor' affecting the result in an asylum case."247

In an attempt to remedy the issue, the United States took measures to provide legal counsel

\footnotetext{
${ }^{239} I d$.

${ }^{240} I d$.

${ }^{241}$ Flores Settlement Agreement, supra note 13.

${ }^{242} I d$.

${ }^{243}$ VOICES OF AFGHAN CHILDREN, supra note 170, at 52.

${ }^{244}$ Levinson, supra note 116.

${ }^{245}$ See Kelly Hill, supra note 151, at 42-5. (discussing the importance of legal counsel for unaccompanied minors); See also Statement of the American Immigration Lawyers Association, supra note 2.

${ }^{246}$ See 8 U.S.C. $\S 1362$ (2006). The language of the statute provides: "In any removal proceedings before an immigration judge and in any appeal proceedings before the Attorney General from any such removal proceedings, the person concerned shall have the privilege of being represented (at no expense to the Government) by such counsel, authorized to practice in such proceedings, as he shall choose."

${ }^{247}$ Statement of the American Immigration Lawyers Association, supra note 2.
} 
for some unaccompanied minors. ${ }^{248}$ This was accomplished via HSA's statutory mandate to ORR to provide assistance to unaccompanied minors in securing legal counsel. ${ }^{249}$ The language of the statute is as follows:

(A) coordinating and implementing the care and placement of unaccompanied alien children who are in Federal custody by reason of their immigration status, including developing a plan to be submitted to Congress on how to ensure that qualified and independent legal counsel is timely appointed to represent the interests of each such child, consistent with the law regarding appointment of counsel that is in effect on November 25, 2002. However, an estimated sixty percent of children in immigration proceedings remain unrepresented. ${ }^{250}$

In order to fulfill its duties under the statute, ORR created the Unaccompanied Children Program ("UAC Program"). ${ }^{251}$ With Congressional funding and the assistance of a pro bono legal program called the Vera Institute, non-profit organizations were able to receive funding to provide legal services to unrepresented persons in immigration custody. ${ }^{252}$ Despite these efforts, the program was not large enough to reach all children in need of legal counsel and approximately sixty percent of unaccompanied minors in immigration proceedings still remain unrepresented. ${ }^{253}$ It is imperative that additional funding be provided to support the expansion of pro-bono legal services for unaccompanied minors to ensure that their rights are protected. ${ }^{254}$

\footnotetext{
${ }^{248}$ See Kelly Hill, supra note 151, at 48-9.

${ }^{249} \mathrm{Id}$.

${ }^{250} 6$ U.S.C. $§ 279$ (b)(1)(A) (2006); See also Kelly Hill, supra note 151, at 48. The statute’s requirement of ORR to assist with appointment of legal counsel for unaccompanied minors is structured in a way to not violate the prohibition of government funding being used to provide public council.

${ }^{251}$ See Kelly Hill, supra note 151, at 48.; See also About Unaccompanied Children's Services, OFFICE OF REFUGEE RESETTLEMENT, http://www.acf.hhs.gov/programs/orr/programs/ucs/about [http://perma.cc/NY99-9JAL].

"Following the Office of Refugee Resettlement (ORR) mission, which is founded on the belief that new arriving populations have inherent capabilities when given opportunities, ORR/ Division of Children's

Services/Unaccompanied Alien Children's program provides unaccompanied children with a safe and appropriate environment until they are released to an appropriate sponsor while their immigration cases proceed."

${ }^{252}$ Kelly Hill, supra note 151 , at 48-9.

${ }^{253} I d$. at 49.

${ }^{254}$ See Statement of the American Immigration Lawyers Association, supra note 2.
} 
Along with providing legal counsel for unaccompanied minors, is the need for the elimination of the use of expedited removal. ${ }^{255}$ Expedited removal is a procedure that allows immigration officers to issue expedited removal orders against non-U.S. citizens, resulting in removals that, except in very limited circumstances, are carried out with no hearing or review by an immigration judge." 256 The process of expedited removal is being used at higher levels in an attempt to deport the unaccompanied minors without having to provide them with any type of international protection. ${ }^{257}$ The use of expedited removal deprives the unaccompanied minors of "meaningful access to asylum and other humanitarian relief." ${ }^{258}$ In order for the United States to fulfill its domestic and international obligations, it must eliminate the use of expedited removal for unaccompanied minors. ${ }^{259}$ It is vital that the cases of the unaccompanied children are heard, so they may receive the protection they need. ${ }^{260}$

Providing care, protection, and legal counsel for the surge or unaccompanied minors will undoubtedly raise questions regarding funding. ${ }^{261}$ Emergency funding of $\$ 3.7$ billion was requested on July $8,2014 .{ }^{262}$ An additional $\$ 9$ million will be made available by the Department

\footnotetext{
${ }^{255} I d$.
}

${ }^{256}$ DHS Announces Latest in Series of Expedited Removal Expansions, 20 IMmigRANTS' RighTS UPDATE, (Mar. 23, 2006), at 1, https://nilc.org/removpsds151.html [http://perma.cc/XFY6-WVV3].; See 8 U.S.C. § 1225(b)(1)(A)(i) (2014). "(i) In general. If an immigration officer determines that an alien (other than an alien described in subparagraph (F)) who is arriving in the United States or is described in clause (iii) is inadmissible under section 212(a)(6)(C) or 212(a)(7) [8 USCS § 1182(a)(6)(C) or 1182(a)(7)], the officer shall order the alien removed from the United States without further hearing or review unless the alien indicates either an intention to apply for asylum under section 208 [8 USCS § 1158] or a fear of persecution." Unaccompanied minors who are placed in expedited removal and provided no access to legal counsel are left voiceless and without a meaningful opportunity to seek the humanitarian relief they need.

${ }^{257}$ See Statement of the American Immigration Lawyers Association, supra note 2.

${ }^{258} I d$.

${ }^{259} \mathrm{Id}$.

${ }^{260} I d$.

${ }^{261}$ NATIONAL CONFERENCE OF STATE LEGISLATURES, supra note 25.

${ }^{262}$ Id. "The FY13 HHS appropriation for the Unaccompanied Minor Program was $\$ 376$ million, increased to $\$ 868$ million in FY14. The FY2015 Administration proposal remains at $\$ 868$ million, due to the unpredictable number of arrivals. In May, 2014, the Office of Management and Budget revised cost projections for FY2015 to $\$ 2.28$ billion for the Unaccompanied Alien Children program in ORR, an increase of $\$ 1.412$ billion from FY14. Funding covers costs for shelter, medical care, support services, and grants to state-licensed facilities for shelter and foster care." 
of Health and Human Services ("HHS") with the objective of providing legal representation for unaccompanied minors through nonprofit organization. ${ }^{263}$ Additionally, "the Senate Appropriations subcommittee on Labor, Health and Human Services and Education indicated it would increase funding for the $\mathrm{UAC}^{264}$ program by $\$ 1.03$ billion in FY 2015 bringing the total funding proposal to $\$ 1.94$ billion." 265 It is imperative that this funding be approved so that unaccompanied minors may receive the protection they require. ${ }^{266}$ Approval of the funding will allow for accommodations to be made that take into account the "best interest of the child."267

\section{Foreign Policy Initiatives}

The Chicago Bar Foundation noted foreign policy initiatives as an important step to solving the issue of unaccompanied minor children arriving in such large numbers to the United States. ${ }^{268}$ Foreign policy initiatives go to the heart of solving the negative treatment of children in the immigration system. ${ }^{269}$ Foreign policy initiatives are one of the most important steps in "resolv[ing] the current humanitarian crisis and refocuses attention to the broader and muchneeded task of comprehensively reforming the U.S. immigration system." 270

The United States is a country that often is found to be "turning inward" to domestic affairs. In failing to engage in the international community and to set an example, the United States is

${ }^{263} I d$.

${ }^{264}$ See Statement of the American Immigration Lawyers Association, supra note 2.; See also About Unaccompanied Children's Services, OFFICE OF REFUGEE RESETTLEMENT, http://www.acf.hhs.gov/programs/orr/programs/ucs/about [http://perma.cc/SKP8-GSKY]. "Following the Office of Refugee Resettlement (ORR) mission, which is founded on the belief that new arriving populations have inherent capabilities when given opportunities, ORR/ Division of Children's Services/Unaccompanied Alien Children's program provides unaccompanied children with a safe and appropriate environment until they are released to an appropriate sponsor while their immigration cases proceed."

265 Statement of the American Immigration Lawyers Association, supra note 2.

${ }^{266} \mathrm{Id}$.

${ }^{267} \mathrm{Id}$.

268 THE CHICAGO BAR FOUNDATION, supra note 39.

${ }^{269} \mathrm{Id}$.

${ }^{270} I d$. 
doing a huge disfavor to human rights, specifically the treatment of children. ${ }^{271 ~ " T h e ~ U n i t e d ~ S t a t e s ~}$ continues to have more influence than any other country in shaping global affairs." ${ }^{272}$ Pretending that the crisis does not exist will not make it disappear. In order to protect children's rights a global initiative must be taken. ${ }^{273}$

This is not to say that the United States has failed to address the issue at all. ${ }^{274}$ Remedying the root problems of large numbers of unaccompanied minors entering the United States will require an extremely complex approach. ${ }^{275}$ The reasons for the unaccompanied minors entering the United States, as discussed earlier in the Note, include "violence by organized armed criminal actors and violence in the home." 276 These factors are what are referred to as the "push factors" of children fleeing. ${ }^{277}$ There is no consensus as to the central reason for the children fleeing their countries of origin, as there is a complex set of interwoven factors. ${ }^{278}$

The reasons are multifaceted and also involve "pull factors" which include a "desire to join family members in the United States and perceptions about U.S. immigration policies." ${ }^{279}$ The "pull factors" are a root cause of the influx that the United States may attempt to remedy with

\footnotetext{
${ }^{271}$ Carl Gershman, America's Purpose and Role in a Changed World, WORLD AFFAIRS (May/June 2014), 2http://www.worldaffairsjournal.org/article/america's-purpose-and-role-changed-world- [http://perma.cc/GU52$\mathrm{Z} 88 \mathrm{Q}]$.

${ }^{272} I d$.

${ }^{273}$ Jean M. Geran, What Can Obama Do About the Surge of Minors from Central America?, FoREIGN POLICY (June 12, 2014, 11:35 AM),

http://shadow.foreignpolicy.com/posts/2014/06/12/what_can_obama_do_about_the_surge_of_minors_from_central _america [http://perma.cc/7YB6-QN2M].

274 Peter J. Meyer, Cong. Research Serv., R43702, Unaccompanied Children from Central America: FOREIGN POLICY CONSIDERATIONS 2 (2014).

${ }^{275} I d$. at 19.

${ }^{276}$ CHILDREN ON THE Run, supra note 20, at 6.

${ }^{277}$ MEYER, supra note 274, at 2.

${ }^{278} I d$.

${ }^{279} I d$. at $1-2$.
} 
foreign policy initiatives. ${ }^{280}$ However, the "pull factors" are a bit more complex and will likely involve an interior solution such as an immigration reform targeted at family reunification. ${ }^{281}$

The United States has taken actions in attempt to remedy the situation and repatriate the children to their countries of origin. ${ }^{282}$ Congress has held numerous hearings, Members have traveled to the regions in crisis, and Congress has introduced legislation to provide funding for foreign policy initiatives. ${ }^{283}$ Senate Bill 2499 is included in the funding proposals, and it would provide \$100 million "to address the root causes pushing children to leave Central America, ensure the safe return and reintegration of such minors, and address the need for family support, foster care, and adoption programs."284

Moreover, House Bill 5013 would provide approximately \$120 million "to address the increased number of unaccompanied children arriving at the U.S. border." 285 The funds would be appropriated as follows: " $\$ 88$ million would support border security initiatives — with a focus on Mexico’s southern border, \$20 million would be used to combat human trafficking and smuggling, \$10 million would support repatriation and reintegration efforts, and \$2 million would support regional dialogue on the issue." 286

While the United States has taken actions to address foreign policy initiatives, those actions are often met with additional obstacles that limit the ability of the United States to remedy the root causes. ${ }^{287}$ The limitations include the, "Central American governments' limited capacities to receive and reintegrate repatriated children, and their inability and/or unwillingness to address the

\footnotetext{
${ }^{280} \mathrm{Id}$. at 2.

${ }^{281} I d$. at $1-2$.

${ }^{282}$ MEYER, supra note 274, at 7.

283 Id. at 9.

${ }^{284} \mathrm{Id}$. at 10.

$285 \mathrm{Id}$. at $10-11$.

${ }^{286} \mathrm{Id}$. at 11.

${ }^{287}$ MEYER, supra note 274, at 10-11.
} 
pervasive insecurity and lack of socioeconomic opportunities in their countries that cause many children to leave." 288

Finding a solution presents an extremely complex set of issues for the United States to take into consideration. ${ }^{289}$ As a leader on the global stage, the United States must identify a workable foreign policy initiative that is targeted at the "push factors." ${ }^{290}$ Furthermore, the United States must also take into consideration the limitations of the foreign policy initiatives and seek to resolve the "pull factors" by focusing on interior solutions such as immigration reform. ${ }^{291}$

\section{CONCLUSION}

The United States has legal obligations both domestically and internationally to protect the unaccompanied immigrant children that enter its borders. While the United States has taken steps toward improving the system in place, a great deal of change must be made in order for the United States to come into compliance with its domestic and international human rights obligations.

For ethical and humanitarian reasons, the inhumane treatment of children within the U.S. detention centers must be stopped. It is imperative that the United States codifies the Flores Settlement Agreement along with providing funding for expansion of the immigration judicial system and to provide legal counsel to all immigrant children. Additionally, the United States should implement a child friendly detention system aimed at protection of children instead of punishment. Finally, it is imperative that the United States engages in foreign policy initiatives in an attempt to identify and remedy the reasons for which the children are fleeing their countries of origin. As a leader, the United States must set an example for the rest of the world to follow, especially given that the lives of children are of central issue.

\footnotetext{
${ }^{288}$ Id. at 11.

${ }^{289}$ Id. at $18-19$.

${ }^{290} I d$. at $2,19$.

${ }^{291} I d$.
} 
Finding a solution to this delicate humanitarian crisis will be nothing short of complicated. A great deal of collaborative effort both domestically and internationally will need to occur in order to reach a resolution. With change comes the need for patience, as it will take time for improvement and implementations to be made to the current system. The United States must focus on both its domestic and international obligations to the unaccompanied minors and maintain its commitment to humanitarian principles. 